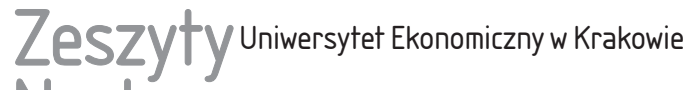 Naukowe
}

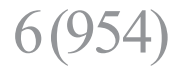

ISSN 1898-6447

Zesz. Nauk. UEK, 2016; 6 (954): 63-80 DOI: 10.15678/ZNUEK.2016.0954.0604

Anna Walecka

Agnieszka Zakrzewska-Bielawska

\section{Metodyka metaanalizy - egzemplifikacja wykorzystania w naukach o zarządzaniu}

\section{Streszczenie}

W artykule przybliżono metodę metaanalizy i możliwości jej wykorzystania w naukach o zarządzaniu. W pierwszej części opracowania omówiono istotę tej metody oraz wskazano jej charakterystyczne cechy. Określono również poszczególne etapy przyjętej przez nią procedury badawczej, ze szczególnym uwzględnieniem różnych miar wykorzystywanych efektów. W dalszej części przedstawiono wybrane przykłady zastosowania metaanalizy do badania problemów z zakresu nauk o zarządzaniu - w sposób szczegółowy omówiono trzy z nich, przy czym w każdej z tych sytuacji inny był cel przyjęcia tej metody. W podsumowaniu wskazano podstawowe ograniczenia wykorzystania metaanalizy jako metody badawczej i określono kierunek jej metodologicznego rozwoju.

Słowa kluczowe: metaanaliza, metodyka, nauki o zarządzaniu, przykłady zastosowania. Klasyfikacja JEL: C18.

\section{Wprowadzenie}

Wśród wielu metod służących krytycznemu przeglądowi literatury coraz większego znaczenia, zwłaszcza w dobie digitalizacji, nabiera metodyka metaanalizy.

Anna Walecka, Politechnika Łódzka, Katedra Zarządzania, 90-924 Łódź, ul. Żeromskiego 116, e-mail: anna.walecka@p.lodz.pl

Agnieszka Zakrzewska-Bielawska, Politechnika Łódzka, Katedra Zarządzania, 90-924 Łódź, ul. Żeromskiego 116, e-mail: agnieszka.zakrzewska-bielawska@p.lodz.pl 
Polega ona na łączeniu wyników różnych badań z zastosowaniem metod statystycznych [Glass 1976, s. 3-8], co pozwala wysnuć wspólne dla tych badań wnioski. Metaanaliza służy z jednej strony do oceny ważności wyników badań naukowych, a $\mathrm{z}$ drugiej do ich syntezy. Pozwala ona określić niezidentyfikowane w badaniach podstawowych relacje, skorygować artefakty, sprawdzić efekty oddziaływania różnych moderatorów oraz odkryć trendy, które mogły być niezauważone przy zastosowaniu innych podejść badawczych [Aguinis et al. 2011, Cooper 2010, Hunter i Schmidt 2015]. W naukach o zarządzaniu metaanaliza dodatkowo może stanowić podstawę formułowania hipotez badawczych, ich testowania, wyjaśniania badanych zjawisk i procesów oraz poszukiwania nowych obszarów badawczych, jak również zaniechania kierunków badań, jeśli w powtarzających się badaniach uzyskiwano niskie współczynniki korelacji [Gondek i Mazur 2014, s. 157-158]. Metaanaliza, koncentrując się na danych ilościowych, zwiększa nie tylko wielkość próby, ale i wielkość efektów (tj. siły związków pomiędzy zmiennymi podlegającymi analizie), przez co wyróżnia się na tle innych metod przeglądu literatury, takich jak przegląd narracyjny, opisowy czy zliczanie głosów [King i He 2005, s. 670]. Przy jej zastosowaniu należy jednak wziąć pod uwagę kilka kluczowych kwestii, jak heterogeniczność wyników badań, ich jakość, dostępność publikacji oraz zrozumiałość otrzymanych z niej wyników [Kleka 2011, s. 99].

Celem artykułu w związku z powyższym jest określenie metodyki metaanalizy i jej wykorzystania w naukach o zarządzaniu. W pierwszej części opracowania omówiono istotę metaanalizy i jej poszczególne etapy, a następnie przedstawiono wybrane przykłady jej zastosowania w badaniach $\mathrm{z}$ zakresu nauk o zarządzaniu.

\section{Cechy i etapy metaanalizy}

Metaanaliza wpisuje się w podejście badawcze zorientowane na dowody. Polega ono na integracji wyników dotychczasowych prac, doświadczeń praktycznych przedsiębiorstw oraz preferencji i wartości konsumentów [Sagan 2009, s. 114-124], przy czym w metaanalizie istotne jest określanie wspólnego mianownika wyników wielu badań i przedstawienie dla nich sumarycznego wniosku statystycznego [Sauerbrei i Blettner 2003].

Rosnąca popularność metaanalizy wynika z zapotrzebowania badaczy na rzetelne informacje o skuteczności różnych narzędzi wykorzystywanych przez firmy. Obecnie dostęp do wyników badań różnych autorów, zarówno z danego kraju, jak i zagranicznych, nie stanowi większego problemu. Naukowcy z różnych części świata podejmują się prób rozwiązania podobnych zagadnień. Ich prace są jednak często realizowane w odmienny sposób [Lipsey i Wilson 2001]. Różnorodność taka wynika z wielu czynników, a różnice między badaniami mogą oddzia- 
ływać na uzyskiwane wyniki i w rezultacie prowadzić nawet do sprzecznych wniosków. Ponadto w nauce istnieje bardzo duże zapotrzebowanie na oryginalne prace badawcze, mające charakter odkrywczy, przynoszące możliwość rozwiązywania problemów badawczych. $Z$ drugiej jednak strony silna jest także potrzeba podejmowania replikacji wykonanych badań ${ }^{2}$ Można to uzasadnić faktem, że weryfikacja założeń badawczych jest możliwa jedynie przy uwzględnieniu wielu wyników badań. Ze statystycznego punktu widzenia problem ten rozwiązuje podejście metaanalityczne, jako najlepsze ze względu na oparty na dowodach sposób analizy danych [Sibińska i Krawiec 2014, s. 82].

Systematyczne łączenie wyników różnych badań ma długą historię, jednak popularność tej metody znacznie wzrosła w latach 90 . XX wieku. W ostatnich dwóch dekadach osiągnięto znaczne postępy w metodach statystycznych wspierających porównywanie wyników wielu badań. Dzisiaj naukowcy poszukują metod umożliwiających rzetelne opisanie zbioru danych pochodzących z różnych źródeł. Historycznie pierwszą taką próbę podjął K. Pearson w 1904 r. [Pearson 1904, s. 1243-1246]. Współczesna era metaanalizy zaczęła się od badań G.V. Glassa² [1976, s. 3-8], który wprowadził termin „metaanaliza” na określenie procedur statystycznych umożliwiających podsumowanie wyników pochodzących z niezależnych od siebie badań. O możliwości łączenia wyników z niezależnie przeprowadzonych badań mówił również R. Rosenthal [1978, s. 185-193]. Podejście to rozwijane m.in. przez R. Rosenthala i D.B. Rubina [Rosenthal i Rubin 1982, s. 500-504; Rosenthal 1995, s. 183-192], L.V. Hedgesa i I. Olkina [1985] oraz J.E. Huntera i F.L. Schmidta [1990, 2004] zaowocowało opracowaniem statystycznych metod pozwalających z wyników różnych badań wyciągnąć wspólny wniosek, oparty na przesłankach statystycznych. Od tego czasu techniki metaanalityczne są szeroko stosowane, szczególnie w naukach behawioralnych, medycznych i fizyce, ale również w naukach o zarządzaniu.

O upowszechnieniu tej metody badawczej zadecydowały jej następujące cechy [The Handbook... 1994; Sack et al. 1987, s. 450-455]:

- integracja i interpretacja zbiorczych wyników różnorodnych badań;

- oparcie analizy na całości literatury zajmującej się danym problemem, zamiast polegania na pojedynczych doniesieniach;

- precyzyjne szacowanie podobieństw i różnic w metodologii poszczególnych prac;

- statystyczna, a nie subiektywna ocena wielkości efektu;

${ }^{1}$ J.E. Hunter wysuwa założenie dokonywania replikacji studiów, przyjmując trzy jej rodzaje: powielenie statystyczne, powielenie naukowe, powielenie konceptualne (szerzej: [Hunter 2001, s. 149]).

${ }^{2}$ Wówczas prace dotyczące metaanalizy spotykały się z intensywną krytyką [Smith i Glass 1977, s. 752-760; Eysenck 1978, s. 517]. 
- rzetelne opracowanie wniosków na podstawie zintegrowanych wyników, co znacznie podnosi wartość badawczą.

Metaanaliza stanowi więc wartościową alternatywę dla przeglądu literatury, gdyż ten przeważnie cechuje się tendencyjnością publikacyjną specjalistycznych czasopism nieuwzględniających badań pozostających poza kręgiem ich zainteresowań, stronniczością autora objawiającą się zbyt subiektywnymi kryteriami selekcyjnymi lub wybiórczą oceną wyników, znaczną rozbieżnością jakości metodologicznej włączonych badań oraz brakiem możliwości analizy zmiennych moderujących [Simon 2010a, s. 4].

W metaanalizie raporty badawcze traktuje się jako obserwacje, a przedmiotem analizy są wyniki wcześniejszych badań wyrażone w formie ilościowej, na przykład jako korelacje czy różnice między średnimi. Na podstawie takich danych oraz dodatkowych informacji opisujących wcześniejsze wyniki oblicza się tzw. wielkości efektu, a następnie poszukuje wśród nich pewnych prawidłowości [Lipsey i Wilson 2001]. Proces metaanalizy składa się z kilku etapów, przy czym różni autorzy przyjmują różny poziom ich uszczegółowienia. Przykładowo A. Gondek i K. Mazur [2014, s. 143] wyróżniają cztery następujące jej etapy:

1) konceptualizacja i operacjonalizacja problemu badawczego na podstawie wstępnej analizy dostępnych wyników badań,

2) gromadzenie danych $z$ wykorzystaniem kryteriów włączania,

3) selekcja i zestawienie wyników badań,

4) analiza statystyczna i formułowanie wniosków.

W. Sauerbrei i M. Blettner [2003] wskazują 10 następujących etapów procesu metaanalizy:

1) zdefiniowanie tematu przeglądu,

2) określenie źródeł, w których można zapoznać się z opublikowanymi i nieopublikowanymi wynikami badań,

3) wybór wszystkich artykułów związanych z tematem przeglądu,

4) sporządzenie wyciągu z niezbędnymi statystykami, ujętymi w odpowiednich tabelach,

5) zdefiniowanie procedury metaanalizy,

6) zbadanie homogeniczności wyników badań,

7) sporządzenie zestawień wyników, np. w postaci graficznej,

8) zbadanie i redukcja w miarę możliwości heterogeniczności między badaniami,

9) obliczenie odpowiedniego współczynnika wielkości efektu,

10) analiza wariancji wielkości efektu w zależności od kryteriów doboru badań.

Jeszcze inaczej etapy metaanalizy postrzega W. Simon [2010a, b, c]. Wyróżnia on: etap stawiania pytań badawczych, przeglądu literatury przedmiotu, kodo- 
wania danych, analizy danych oraz etap wnioskowania, których charakterystykę syntetycznie przedstawiono w tabeli 1 .

Według tego autora jakość metodologiczna metaanalizy zależy od tego, w jakim stopniu porównywane badania odnoszą się do zbliżonego konstruktu mierzonego przez standardowe narzędzia badawcze i analizowanego z użyciem takich samych procedur statystycznych. Pytania badawcze należy więc sformułować a priori, a wszystkie konstrukty powinny być jednoznacznie i szczegółowo zdefiniowane [Simon 2010a, s. 6]. Na tym etapie należy jasno zdefiniować kryteria dotyczące włączania lub niewłączania badań do metaanalizy. Jednocześnie metodologia badań włączanych do metaanalizy powinna podlegać rygorystycznej ocenie.

Tabela 1 . Podstawowe etapy metaanalizy

\begin{tabular}{|c|c|c|}
\hline Etap & Istota etapu & Cele szczegółowe \\
\hline $\begin{array}{l}\text { Pytania } \\
\text { badawcze }\end{array}$ & $\begin{array}{l}\text { - formułowanie pytań } \\
\text { a priori } \\
\text { - precyzyjna operacjo- } \\
\text { nalizacja konstruktów } \\
\text { badawczych }\end{array}$ & $\begin{array}{l}\text { - uwzględnienie wszelkich parametrów badania, } \\
\text { takich jak: rodzaj i wielkość badanej grupy, wielkość } \\
\text { efektu, narzędzia badawcze, metody statystyczne } \\
\text { i inne, } \\
\text { - koncentrowanie się na badaniach podejmujących } \\
\text { szczegółowo badane kwestie, } \\
\text { - zdefiniowanie kryteriów włączania i niewłączania } \\
\text { badań do metaanalizy, } \\
\text { - stosowanie skali kategoryzującej badania według } \\
\text { wartości metodologicznej }\end{array}$ \\
\hline $\begin{array}{l}\text { Przegląd } \\
\text { literatury } \\
\text { przedmiotu }\end{array}$ & $\begin{array}{l}\text { - dotarcie do jak naj- } \\
\text { większej liczby badań } \\
\text { - określanie i oszaco- } \\
\text { wanie tendencyjności } \\
\text { publikacyjnej }\end{array}$ & $\begin{array}{l}\text { - stosowanie synonimów i wyrazów bliskoznacznych, } \\
\text { - korzystanie z elektronicznych baz danych z arty- } \\
\text { kułami, rozdziałami, książkami oraz nieopublikowa- } \\
\text { nymi pracami doktorskimi i magisterskimi, } \\
\text { - prowadzenie ręcznego przeglądu spisu literatury, } \\
\text { - docieranie do streszczeń konferencyjnych, } \\
\text { - kontaktowanie się z kluczowymi badaczami } \\
\text { z danej dziedziny, } \\
\text { - określenie przyczyn potencjalnej tendencyjności } \\
\text { publikacyjnej, } \\
\text { - wybór metody szacującej tendencyjność publika- } \\
\text { cyjną }\end{array}$ \\
\hline $\begin{array}{l}\text { Kodowanie } \\
\text { danych }\end{array}$ & $\begin{array}{l}\text { rzetelne kodowanie } \\
\text { danych z poszczegól- } \\
\text { nych metaanalizowa- } \\
\text { nych prac }\end{array}$ & $\begin{array}{l}\text { - jasne i precyzyjne określenie zmiennych oraz pro- } \\
\text { cedury kodowania, } \\
\text { - osobne kodowanie badań „mocnych” metodolo- } \\
\text { gicznie, a osobne „słabych”, } \\
\text { - kodowanie przez dwa niezależne dwuosobowe } \\
\text { zespoły koderów, } \\
\text { - przeszkolenie i monitorowanie pracy koderów, } \\
\text { - ocena stopnia rzetelności między koderami - staty- } \\
\text { styka kappa }\end{array}$ \\
\hline
\end{tabular}


cd. tabeli 1

\begin{tabular}{|c|c|c|}
\hline Etap & Istota etapu & Cele szczegółowe \\
\hline Analiza danych & $\begin{array}{l}\text { - wybór i obliczanie } \\
\text { „wielkości efektu” } \\
\text { - obliczanie „sukcesu } \\
\text { badawczego” } \\
\text { - testowanie homoge- } \\
\text { niczności } \\
\text { - poszukiwanie mode- } \\
\text { ratorów i mediatorów } \\
\text { - modele wielkości } \\
\text { efektu } \\
\text { - przycinanie danych } \\
\text { - ocena replikacji } \\
\text { metaanalizy }\end{array}$ & $\begin{array}{l}\text { - wybór wielkości efektu w zależności od: a) pro- } \\
\text { cedur statystycznych użytych w analizowanych } \\
\text { badaniach; b) rodzaju zmiennych, } \\
\text { - kategoryzowanie wielkości efektu, } \\
\text { - przeliczanie wartości między poszczególnymi } \\
\text { wielkościami efektu, } \\
\text { - przeliczanie wielkości efektu na centyle i procenty, } \\
\text { - stosowanie binominalnej wielkości efektu, } \\
\text { - opisanie przyczyn heterogeniczności we włączo- } \\
\text { nych badaniach, } \\
\text { - ocena homogeniczności, } \\
\text { - wybór testu homogeniczności, } \\
\text { - testowanie hipotezy homogeniczności, } \\
\text { - kategoryzowanie procentu heterogeniczności, } \\
\text { - opisanie i testowanie zmiennych moderujących, } \\
\text { - opisanie i testowanie zmiennych mediujących, } \\
\text { - korzystanie ze stałego modelu wielkości efektu - } \\
\text { w przypadku stwierdzonej homogeniczności, } \\
\text { - korzystanie z losowego modelu wielkości efektu - } \\
\text { w przypadku stwierdzonej heterogeniczności, } \\
\text { - korzystanie z modelu hybrydowego - w niejedno- } \\
\text { znacznych przypadkach, } \\
\text { - ważenie wielkości efektu, } \\
\text { - określenie wyników nietypowo odstających od } \\
\text { pozostałych rezultatów, } \\
\text { - przycinanie odstających danych, } \\
\text { - porównanie wielkości efektu, } \\
\text { - testy istotności }\end{array}$ \\
\hline Wnioskowanie & $\begin{array}{l}\text { wyciąganie wniosków } \\
\text { istotnych } \\
\text { metodologicznie }\end{array}$ & $\begin{array}{l}\text { - wyciąganie wniosków na podstawie przyjętych } \\
\text { założeń, } \\
\text { - ostrożne wnioskowanie w przypadku: a) prac bazu- } \\
\text { jących na małej liczbie publikacji, b) prac cechują- } \\
\text { cych się znaczną heterogenicznością }\end{array}$ \\
\hline
\end{tabular}

Źródło: opracowanie na podstawie [Simon 2010a, s. 5-6].

Metaanalizę należy poprzedzić szczegółowym przeglądem zasobów literatury, który zakłada posługiwanie się synonimami i wyrazami bliskoznacznymi słów kluczowych. Zdecydowanie zwiększa to szansę na dotarcie do większej liczby badań. Ważne jest, by dotrzeć zarówno do tej literatury, która została opublikowana (rodzimej i obcojęzycznej), jak i tej - w miarę możliwości „szufladowej”.

Kodowanie danych wymaga jasno określonej procedury i precyzji w jej przestrzeganiu. Szanse na większą rzetelność rosną, jeżeli praca włączona do meta- 
analizy jest kodowana przez dwa niezależne zespoły koderów. W celu zminimalizowania potencjalnych rozbieżności w kodowaniu poszczególnych danych koderzy powinni być dokładnie w tym zakresie przeszkoleni.

Po etapie kodowania rozpoczyna się żmudny proces analizy danych. Na tym etapie niezwykle ważne jest, by zastosować właściwe miary wielkości efektów ${ }^{3}$. Są one pochodną głównego pytania badawczego metaanalizy, schematu porównywanych badań i rodzaju analizowanych zmiennych. Aby poradzić sobie z problemem porównywalności wyników, wypracowano różne rodzaje miar wielkości efektów. J. Matera i J. Czapska [2014, s. 61] dzielą je na trzy kategorie: miary wykorzystujące współczynniki korelacji, miary opierające się na wartościach średnich oraz miary dla zmiennych dychotomicznych (w których zmienna wyjaśniana przyjmuje dwie wartości: 0 lub 1, zwykle odzwierciedlające wystąpienie określonego wydarzenia lub jego brak). Miary te przedstawiono w tabeli 2.

Tabela 2. Wybrane miary efektów wykorzystywane w metaanalizie

\begin{tabular}{|c|c|}
\hline \multicolumn{2}{|r|}{ Miary oparte na korelacjach lub wyjaśnianej wariancji } \\
\hline$r$ & $\begin{array}{l}\text { Współczynnik korelacji liniowej Pearsona wyraża liniową zależność między } \\
\text { dwiema zmiennymi (zmierzonymi co najmniej na skali interwałowej). Korelacja } \\
\text { jest silna, jeśli może być opisana za pomocą linii prostej }\end{array}$ \\
\hline$r^{2}$ & $\begin{array}{l}\text { Współczynnik determinacji - } r \text { podniesione do kwadratu. Informuje o tym, jaki } \\
\text { procent zmienności zmiennej zależnej (objaśnianej } Y \text { ) jest wyjaśniany przez } \\
\text { zmienną niezależną (czynnik - zmienna objaśniająca, predyktor } X \text { ) }\end{array}$ \\
\hline$R^{2}$ & $\begin{array}{l}\text { Współczynnik wielorakiej determinacji - stopień, w jakim dwie lub więcej zmien- } \\
\text { nych objaśniających (niezależnych lub X) jest powiązanych ze zmienną objaśnianą } \\
\text { (zmienna zależna } Y \text { ) }\end{array}$ \\
\hline$\eta^{2}$ & $\begin{array}{l}\text { Eta-kwadrat - wskaźnik siły efektu: pokazuje, jaki procent zmienności w zakresie } \\
\text { zmiennej objaśnianej (zmiennej zależnej) jest wyjaśniany przez zmienną objaśnia- } \\
\text { jącą (zmienną niezależną) }\end{array}$ \\
\hline$\omega^{2}$ & Omega-kwadrat - względnie nieobciążony wariant eta-kwadrat \\
\hline$\rho\left(\operatorname{lub} r_{s}\right)$ & $\begin{array}{l}\text { Rho Spearmana - współczynnik korelacji dla zmiennych porządkowych. Oblicza } \\
\text { się go na podstawie rang, a nie wartości }\end{array}$ \\
\hline$r_{p b}$ & $\begin{array}{l}\text { Współczynnik korelacji dwuseryjnej - do obliczania siły związku między zmienną } \\
\text { ciągłą a dychotomiczną }\end{array}$ \\
\hline$V$ Cramera & Wykorzystywany do pomiaru siły związku zmiennych nominalnych \\
\hline
\end{tabular}

${ }^{3}$ Wielkość efektu jest ilościową miarą siły zjawiska obliczaną na podstawie danych. Stosuje się ją do mierzenia wpływu pewnego czynnika na wynik ogólny grupy, czyli siły związku między zmienną niezależną a zmienną zależną. Wielkość efektu nie jest zależna od wielkości próby, a jego interpretacja opiera się na założeniu o normalności rozkładów wyników porównywanych grup [King i Minium 2009]. 
cd. tabeli 2

\begin{tabular}{|c|l|}
\hline \multicolumn{2}{|c|}{ Porównanie grup oparte na ciągłej zmiennej wyjaśnianej } \\
\hline$d$ & $\begin{array}{l}d \text { Cohena - standaryzowana różnica średnich, tj. różnica między średnimi wyra- } \\
\text { żona w jednostkach odchylenia standardowego }\end{array}$ \\
\hline$g$ & $g$ Hedgesa - skorygowana różnica średnich \\
\hline$\Delta$ & $\begin{array}{l}\text { Delta Glassa - standaryzowana różnica średnich, w których różnica jest wyrażona } \\
\text { w jednostkach odchylenia standardowego w grupie kontrolnej }\end{array}$ \\
\hline \multicolumn{2}{|c|}{ Porównanie grup oparte na dychotomicznej zmiennej wyjaśnianej } \\
\hline$R R$ & $\begin{array}{l}\text { Iloraz szans - porównuje szansę wystąpienia zdarzenia w jednej grupie z szansą } \\
\text { wystąpienia tego zdarzenia w drugiej grupie }\end{array}$ \\
\hline$R R$ & $\begin{array}{l}\text { Względne ryzyko - porównanie prawdopodobieństwa wystąpienia zdarzenia w jed- } \\
\text { nej grupie z prawdopodobieństwem wystąpienia tego wydarzenia w drugiej grupie }\end{array}$ \\
\hline$R D$ & $\begin{array}{l}\text { Różnica ryzyk - różnica między prawdopodobieństwem wystąpienia zdarzenia } \\
\text { w dwóch grupach }\end{array}$ \\
\hline
\end{tabular}

Źródło: [Matera i Czapska 2014, s. 61-62].

Jak wynika z tabeli 2, istnieje wiele miar wielkości efektu. W metaanalizie najczęściej wykorzystywane są miary $d$ Cohena, $g$ Hedgesa i delta Glassa [Rosenthal i Rubin 2003, s. 492-496; Zakrzewska 2004, s. 342-478]. Często również miernikiem efektów jest iloraz szans (OR, odds ratio) [Barylski, Górska-Ciebiada i Ciebiada 2011, s. 324].

Metaanalizę wieńczy etap wyciągania wniosków. Na tym etapie warto pamiętać, że procedura ta ułatwia precyzyjniejszą ocenę skali uzyskanych wyników, nie zwiększa zaś trafności ani wiarygodności rezultatów. Dlatego też wszelkie wnioskowanie powinno być powściągliwe, szczególnie w przypadku prac bazujących na małej liczbie publikacji ${ }^{4}$ oraz cechujących się znaczną heterogenicznością [Simon 2010c, s. 28].

Przyjęty rygor metodologiczny jest kluczową kwestią dla prawidłowo przeprowadzonej metaanalizy, a tym samym dla rzetelności uzyskiwanych z niej wniosków i osiągnięcia celów, które przed nią postawiono.

\section{Metaanaliza w naukach o zarządzaniu - wybrane przykłady}

Metaanaliza jako jedna z metod krytycznej analizy przedmiotu stosunkowo często wykorzystywana jest w naukach o zarządzaniu. Badacze bowiem, poszu-

\footnotetext{
${ }^{4} \mathrm{~W}$ literaturze sugeruje się, że minimalna liczba badań wykorzystanych w metaanalizie wynosi 15 [Field 2001, s. 162], bowiem przy mniejszej ich liczbie ryzyko popełnienia błędu pierwszego rodzaju jest zbyt wysokie, a jego poziom maleje wraz ze wzrostem liczby badań. Błąd pierwszego rodzaju popełnia się wtedy, gdy na podstawie przeprowadzonej analizy statystycznej stwierdza się fałszywość weryfikowanej hipotezy, gdy w rzeczywistości jest ona prawdziwa.
} 
kując luk poznawczo-badawczych, starają się dokonać możliwie najszerszego i rzetelnego przeglądu dotychczasowej wiedzy. Przykłady zastosowania metaanalizy do wybranych problemów zarządzania przedstawiono w tabeli 3, przy czym szczegółowe jej wykorzystanie omówiono w stosunku do trzech przykładowych zagadnień, obrazujących różne cele jej wykorzystania.

Tabela 3. Przykłady zastosowań metaanalizy do wybranych problemów zarządzania

\begin{tabular}{|c|c|}
\hline Autorzy & Problem badawczy \\
\hline F. Damanpour [1991] & $\begin{array}{l}\text { związek pomiędzy innowacjami a } 13 \text { czynnikami organizacyj- } \\
\text { nymi wraz z określeniem moderatorów tych relacji }\end{array}$ \\
\hline C. Campbell-Hunt [2000] & $\begin{array}{l}\text { empiryczne zagregowanie charakterystyk strategii konku- } \\
\text { rencyjnych poprzez trzy metaanalizy: 1) wymiarów strategii } \\
\text { konkurencyjnej (analizy czynnikowe), 2) projektowania strategii } \\
\text { konkurencyjnych (analizy skupień), 3) oceny teoretycznego } \\
\text { paradygmatu realizacji strategii konkurencyjnych }\end{array}$ \\
\hline $\begin{array}{l}\text { J.P. Meyer, D.J. Stanley, } \\
\text { L. Herscovitch, L. Topolnyt- } \\
\text { sky [2002] }\end{array}$ & $\begin{array}{l}\text { - relacje pomiędzy afektywnym, ciągłym i normatywnym zaan- } \\
\text { gażowaniem organizacyjnym } \\
\text { - relacje między trzema formami zaangażowania i zmiennymi } \\
\text { uznanymi za ich antecedencje, korelacje i skutki w trzyskładni- } \\
\text { kowym modelu Meyera i Allena }\end{array}$ \\
\hline $\begin{array}{l}\text { D.R. King, D.R. Dalton, } \\
\text { C.M. Daily, J.G. Covin } \\
\text { [2004] }\end{array}$ & $\begin{array}{l}\text { wpływ najczęściej badanych antecedencji na efektywność orga- } \\
\text { nizacyjną przedsiębiorstwa po akwizycji }\end{array}$ \\
\hline $\begin{array}{l}\text { T.R. Crook, D.J. Ketchen, } \\
\text { J.G. Combs, S.Y. Todd [2008] }\end{array}$ & $\begin{array}{l}\text { odpowiedź na pytanie: w jakim stopniu zasoby strategiczne } \\
\text { przyczyniają się do uzyskiwanych przez firmę wyników (efek- } \\
\text { tywności organizacyjnej) i jaka jest różnica w tej relacji z uwagi } \\
\text { na pomiar wyników (uwzględnienie lub nieuwzględnienie } \\
\text { apropriacji wartości)? }\end{array}$ \\
\hline $\begin{array}{l}\text { P.P. Heugens, M.W. Lander } \\
\text { [2009] }\end{array}$ & $\begin{array}{l}\text { poszukiwanie odpowiedzi na trzy kluczowe i kontrowersyjne } \\
\text { problemy teorii instytucjonalnej: 1) czy zachowania organiza- } \\
\text { cyjne są produktem struktury społecznej czy agencji? 2) czy } \\
\text { zgodność z normami instytucjonalnymi wzmacnia czy osłabia } \\
\text { efektywność organizacyjną? 3) jakie czynniki moderują procesy } \\
\text { izomorficzne? }\end{array}$ \\
\hline $\begin{array}{l}\text { P. Junni, R.M. Sarala, } \\
\text { V. Taras, S.Y. Tarba [2013] }\end{array}$ & $\begin{array}{l}\text { wpływ organizacyjnej „oburęczności” (organizational ambidex- } \\
\text { terity) na wyniki firmy (performance) oraz znaczenie modera- } \\
\text { torów kontekstowych i metodologicznych }\end{array}$ \\
\hline $\begin{array}{l}\text { P. Cankurtaran, F. Langerak, } \\
\text { A. Griffin [2013] }\end{array}$ & $\begin{array}{l}\text { związek między szybkością rozwoju nowego produktu a jego } \\
\text { sukcesem analizowany w sposób holistyczny, z uwzględnieniem } \\
\text { antecedencji tej relacji w odniesieniu do różnych wymiarów } \\
\text { efektywności nowego produktu }\end{array}$ \\
\hline $\begin{array}{l}\text { B.S. Vanneste, P. Puranam, } \\
\text { T. Kretschmer [2014] }\end{array}$ & związek zaufania i czasu trwania relacji wymiany \\
\hline
\end{tabular}

Źródło: opracowanie własne. 
Badacze podejmujący problem relacji pomiędzy organizacyjną „oburęcznością"5 a wynikami przedsiębiorstwa [Junni et al. 2013, s. 299-312] wykorzystali metaanalizę do sprawdzenia tej zależności w kontekście oddziaływania różnych moderatorów. W tym celu wykorzystali trzy pełnotekstowe bazy czasopism elektronicznych, jak: Google Scholar, EBSCO i Web of Science. Na etapie gromadzenia danych wyodrębniono dwa zestawy danych. Pierwszy obejmował te prace, w których wskazano współczynnik korelacji $(r)$ pomiędzy wyraźnie określonym konstruktem „oburęczności” a wynikami firmy, drugi zaś te prace, w których wskazano współczynnik korelacji $(r)$ pomiędzy wymiarami „oburęczności” (tj. eksploracją i eksploatacją) a wynikami przedsiębiorstwa. Z kolei prace obejmujące obydwa te rodzaje korelacji zostały uwzględnione w obu zestawach danych. W ten sposób w pierwszym zestawie danych znalazło się 25 prób badawczych, a w drugim 110. Kolejno dokonano kodowania danych statystycznych i informacji o przeprowadzonym badaniu przez dwóch niezależnych badaczy, a stopień zgodności dwukrotnego kodowania tych samych zmiennych sprawdzono z wykorzystaniem współczynnika kappa Cohena, który dla poszczególnych kodowanych zmiennych wynosił od 0,73 do 0,94. Niejasne przypadki kodujący rozstrzygali w trakcie dyskusji. Następnie autorzy oszacowali wielkość efektu na podstawie współczynników korelacji $(r)$ dla obu zestawów danych, określając przy tym ważoną metaanalityczną wielkość efektu - zarówno ogólną, jak i skorygowaną o rzetelność pomiaru. W celu ujednolicenia wielkości efektów oraz dla potrzeb analizy homogeniczności obliczono odchylenia standardowe wielkości efektów oraz wartości chi-kwadrat statystyk jednorodności, określając również górne i dolne granice przedziału ufności i przedziału wiarygodności. Metaanaliza badań sprawdzających związek pomiędzy organizacyjną ,oburęcznością" jako wyraźnie wyodrębnionym konstruktem (zestaw danych 1), jak również pomiędzy eksploracją i eksploatacją jako składowymi „oburęczności” (zestaw danych 2) a wynikami firmy dała pozytywną i statystycznie istotną średnią wielkość efektu w obu przypadkach.

Następnie sprawdzono tę relację z perspektywy moderatorów kontekstowych i metodologicznych, do których zaliczono: sposób pomiaru „oburęczności”, sposób pomiaru wyników firmy, poziom analizy, metodę zbierania danych oraz sektor działalności badanych przedsiębiorstw. Badacze szacowali ogólną zmienność wielkości efektu, wykorzystując te same wskaźniki, a uzyskane wyniki potwierdziły ich istnienie, przy czym siły związku pomiędzy poszczególnymi zmiennymi były różne. „Oburęczność organizacyjna” jest szczególnie istotna

\footnotetext{
${ }^{5}$ Przez „oburęczność organizacyjną” należy rozumieć zdolność strategiczną przedsiębiorstwa wiążącą się z poszukiwaniem równowagi pomiędzy eksploracją a eksploatacją, wymagającą z jednej strony elastyczności, innowacyjności, szukania okazji, zaś z drugiej ukierunkowania na koszty, zyski i wydajność (zob. [Zakrzewska-Bielawska 2016, s. 20]).
} 
dla wyników osiąganych w sektorach nieprodukcyjnych i przy uwzględnieniu wyższego poziomu analizy (poziomu firmy, aliansu). Równocześnie relacja ta jest silniejsza, gdy „oburęczność” mierzona jest przez kombinację eksploracji i eksploatacji (jako dwóch oddzielnych wymiarów), gdy wyniki firmy opierają się na miarach percepcji oraz gdy badania mają charakter przekrojowy i wykorzystywanych jest wiele metod. Przeprowadzona przez badaczy metaanaliza ujawniła luki i słabości metodologiczne w badaniach nad „oburęcznością organizacyjną” i wynikami firmy, wskazując jednocześnie kierunki dalszych badań.

Jako drugi przykład zastosowania metaanalizy wybrano badania nad związkiem zasobów strategicznych z efektywnością firmy [Crook et al. 2008, s. 1141-1154]. Metoda ta została wykorzystana w celu testowania hipotez. Autorzy na podstawie przeglądów literatury postawili trzy hipotezy badawcze: H1 - posiadanie zasobów zidentyfikowanych przez badaczy jako strategiczne jest dodatnio związane z efektywnością organizacyjną; H2 - miary zasobów, które spełniają kryteria teorii zasobowej ${ }^{6}$, mają silniejszy pozytywny związek z efektywnością organizacyjną niż miary, które tych kryteriów nie spełniają; H3 - relacja strategicznych zasobów z efektywnością jest silniejsza, gdy miary efektywności są niezależne od potencjalnej apropriacji wartości, niż wtedy, gdy są od niej zależne. W celu znalezienia adekwatnych artykułów autorzy przeszukali elektroniczne bazy tekstów naukowych ProQuest (ABI Inform), EBSCO (Business Source Premier) oraz JSTOR, używając przy tym słów kluczowych, takich jak: zasób (resource), oparty na zasobach (resource-based), efektywność (performance). Poszukiwano artykułów z okresu 1991-2005. Wyniki dały 127 prób badawczych zawartych w 125 artykułach, z czego ponad połowa została opublikowana w czołowych dla dyscypliny czasopismach, takich jak: „Strategic Management Journal” (42 badania) czy „Academy of Management Journal” (28 badań). Następnie badania podlegały niezależnemu kodowaniu przez dwóch badaczy, którzy zgodzili się co do przyjętych kodów w 92\%, a pozostałe rozbieżności zostały rozwiązane poprzez dyskusję. Łącznie badania objęły 29561 organizacji. W stosunku do hipotezy 1 kodem była stwierdzona korelacja pomiędzy strategicznymi zasobami a efektywnością organizacyjną. Dla hipotezy 2 jako kod przyjęto spełnienie przynajmniej jednego warunku teorii zasobowej, zaś dla hipotezy 3 pomiar efektywności uwzględniający (lub nie) apropriację wartości. Wielkości efektu oszacowano jako średnią korelacji (r) ze wszystkich badań ważoną wielkością prób, przy czym przedziały ufności określono dla każdego $\bar{r}$. Obliczono także wariancje z poszczególnych populacji. Wykonano również

\footnotetext{
${ }^{6}$ Zasoby strategiczne to takie, które spełniają kryteria zaproponowane przez J.B. Barneya (nazywane często kryteriami teorii zasobowej), czyli są cenne, rzadkie, trudne do imitacji i (lub) substytucji [Barney 1991, s. 99-120].
} 
testy odporności po fakcie (post hoc robustness tests), aby określić potencjalne moderatory badanej relacji.

W wyniku przeprowadzonej metaanalizy badacze potwierdzili postawione hipotezy oraz zauważyli, że zasoby strategiczne rozpatrywane z perspektywy łańcucha wartości lub w grupach zasobów ludzkich, materialnych i niematerialnych pozytywnie wpływają na efektywność, co sugeruje rozwijanie wielu rodzajów zasobów. Z drugiej strony nie stwierdzono statystycznie istotnych różnic w badanej relacji w zależności od rodzaju działalności, poziomu dywersyfikacji i wielkości firmy, co oznacza, że wpływ strategicznych zasobów na efektywność organizacyjną jest ważny i relatywnie stały w wielu różnych kontekstach. Na podstawie uzyskanych wyników badacze postawili szereg istotnych pytań, wyznaczających ciekawe nurty dalszych eksploracji naukowych.

Trzecim przykładem zastosowania metaanalizy w naukach o zarządzaniu są badania poświęcone związkowi zaufania i czasu trwania relacji wymiany [Vanneste, Puranam i Kretschmer 2014, s. 1891-1902]. Jej celem było wyjaśnienie badanego zjawiska z perspektywy dotychczasowych (często różnych i sprzecznych) wyników, by na tej podstawie można było teoretyzować na temat mechanizmów wpływających na związek między zaufaniem i czasem trwania relacji. Autorzy wykorzystali bazę danych EBSCO (Business Source Complete) i ProQuest (PsycINFO), szukając artykułów dla okresu od 1887 do 2010 r. Jako słowa kluczowe wyznaczyli: zaufanie (trust), łącznie z co najmniej jednym $\mathrm{z}$ takich słów, jak: historia (history), czas trwania (duration), długość (length), czas (time) lub częstotliwość (frequency) oraz z co najmniej jednym z takich słów, jak: dane (data), empiryczny (empirical), test (test), statystyczny (statistical), wynik (finding), rezultat (result) lub dowód (evidence). Następnie wybrano artykuły z 17 kluczowych dla dyscypliny i problemu badawczego czasopism. Kryterium włączenia tekstu do metaanalizy było określone trzema warunkami: 1) konstrukt zaufania rozumiany jako stan psychologiczny oparty na pozytywnych oczekiwaniach wobec intencji i zachowań innych osób, uwzględniający podatność na zranienie, 2) istnienie korelacji pomiędzy zaufaniem a czasem trwania relacji wymiany, 3) badanie przeprowadzone na poziomie interpersonalnym lub międzyorganizacyjnym. Kodowanie przeprowadzono według wartości współczynnika korelacji oraz wielkości próby. Ostatecznie do metaanalizy zakwalifikowano 39 badań, obejmujących łącznie 9632 obserwacje. W następnej kolejności dokonano korekty zidentyfikowanych współczynników korelacji ze względu na stronniczość wynikającą z trzech artefaktów statystycznych: 1) dychotomizacji zmiennej dotyczącej czasu trwania relacji, 2) błędu pomiaru w zmiennej zaufania, 3) błędu próby. Następnie oszacowano średnią korelację pomiędzy zaufaniem a czasem trwania relacji ważoną wielkością prób, wykonano analizę wariancji oraz test chi-kwadrat w celu sprawdzenia homogeniczności. Uzyskane wyniki 
wskazały, że dwuwymiarowa korelacja między zaufaniem i czasem trwania relacji wymiany jest dodatnia, ale niska oraz że istnieją niezidentyfikowane czynniki, które moderują tę relację. Wyniki są niezależne od poziomu analizy (interpersonalny versus międzyorganizacyjny). To z kolei stało się przesłanką do dalszego teoretyzowania poprzez określenie mechanizmów mających wpływ na związek pomiędzy zaufaniem a czasem trwania relacji wymiany. Autorzy określili cztery takie mechanizmy: początkowe nastawienie do strony relacji i jego korekta $\mathrm{z}$ czasem jej trwania, zmiany w wartości relacji, identyfikacja ze stroną relacji oraz selekcja partnerów relacji oparta na zaufaniu i na podstawie ich analizy zaproponowali kilka hipotez, które mogą stanowić przedmiot dalszych badań.

Zastosowanie metaanalizy w omówionych trzech przykładach wraz z płynącymi z niej wnioskami syntetycznie przedstawiono w tabeli 4 .

Tabela 4. Zastosowanie metaanalizy w wybranych przykładach

\begin{tabular}{|c|c|c|c|}
\hline \multirow[b]{2}{*}{ Wyszczególnienie } & \multicolumn{3}{|c|}{ Omówione przykłady wykorzystania metaanalizy } \\
\hline & P. Junni et al. [2013] & T.R. Crook et al. [2008] & $\begin{array}{c}\text { B.S. Vanneste, P. Pura- } \\
\text { nam i T. Kretschmer } \\
{[2014]}\end{array}$ \\
\hline $\begin{array}{l}\text { Problem } \\
\text { badawczy }\end{array}$ & $\begin{array}{l}\text { wpływ organizacyj- } \\
\text { nej „oburęczności” } \\
\text { na wyniki firmy oraz } \\
\text { znaczenie moderatorów } \\
\text { kontekstowych i meto- } \\
\text { dologicznych }\end{array}$ & $\begin{array}{l}\text { związek zasobów } \\
\text { strategicznych z efek- } \\
\text { tywnością firmy wraz } \\
\text { z identyfikacją poten- } \\
\text { cjalnych moderatorów } \\
\text { tej relacji }\end{array}$ & $\begin{array}{l}\text { związek pomiędzy } \\
\text { zaufaniem a cza- } \\
\text { sem trwania relacji } \\
\text { wymiany }\end{array}$ \\
\hline Cel metaanalizy & $\begin{array}{l}\text { sprawdzenie relacji } \\
\text { i efektów oddziaływa- } \\
\text { nia różnych modera- } \\
\text { torów }\end{array}$ & testowanie hipotez & $\begin{array}{l}\text { wyjaśnienie badanego } \\
\text { zjawiska, rozwój teorii }\end{array}$ \\
\hline $\begin{array}{l}\text { Gromadzenie } \\
\text { danych }\end{array}$ & $\begin{array}{l}\text { Google Scholar, } \\
\text { EBSCO, Web of } \\
\text { Science }\end{array}$ & $\begin{array}{l}\text { ProQuest, EBSCO, } \\
\text { JSTOR }\end{array}$ & EBSCO, ProQuest \\
\hline $\begin{array}{l}\text { Kryterium } \\
\text { włączania }\end{array}$ & $\begin{array}{l}\text { zależność identyfiko- } \\
\text { wana współczynnikiem } \\
\text { korelacji }(r)\end{array}$ & $\begin{array}{l}\text { okres analizy, korelacja } \\
\text { między zmiennymi, } \\
\text { spełnienie przynaj- } \\
\text { mniej jednego warunku } \\
\text { teorii zasobowej, } \\
\text { pomiar efektywno- } \\
\text { ści uwzględniający } \\
\text { (lub nie) apropriację } \\
\text { wartości }\end{array}$ & $\begin{array}{l}\text { okres analizy, okre- } \\
\text { ślony konstrukt } \\
\text { rozumienia zaufania, } \\
\text { korelacja pomiędzy } \\
\text { zmiennymi, badania na } \\
\text { poziomie interperso- } \\
\text { nalnym lub międzyor- } \\
\text { ganizacyjnym }\end{array}$ \\
\hline Kodowanie & dwa zestawy danych & $\begin{array}{l}\text { w zależności od posta- } \\
\text { wionych trzech hipotez }\end{array}$ & $\begin{array}{l}\text { według współczynnika } \\
\text { korelacji i wielkości } \\
\text { próby }\end{array}$ \\
\hline
\end{tabular}


cd. tabeli 4

\begin{tabular}{|c|c|c|c|}
\hline \multirow[b]{2}{*}{ Wyszczególnienie } & \multicolumn{3}{|c|}{ Omówione przykłady wykorzystania metaanalizy } \\
\hline & P. Junni et al. [2013] & T.R. Crook et al. [2008] & $\begin{array}{c}\text { B.S. Vanneste, P. Pura- } \\
\text { nam i T. Kretschmer } \\
{[2014]}\end{array}$ \\
\hline $\begin{array}{l}\text { Wnioskowanie } \\
\text { statystyczne }\end{array}$ & $\begin{array}{l}\text { ważona metaanali- } \\
\text { tyczna wielkość efektu, } \\
\text { odchylenie standar- } \\
\text { dowe wielkości efektu, } \\
\text { wartość chi-kwadrat } \\
\text { statystyk jednorodności }\end{array}$ & $\begin{array}{l}\text { średnia wielkości próby } \\
\text { ważona korelacjami }(r) \text {, } \\
\text { analizy wariancji, testy } \\
\text { odporności po fakcie }\end{array}$ & $\begin{array}{l}\text { średnia ważona } \\
\text { korelacji pomiędzy } \\
\text { zmiennymi, analiza } \\
\text { wariancji, wartość } \\
\text { chi-kwadrat statystyk } \\
\text { jednorodności }\end{array}$ \\
\hline Główne wnioski & $\begin{array}{l}\text { - pozytywne i istotne } \\
\text { wielkości efektu, silna } \\
\text { obecność moderatorów, } \\
\text { - badania przekrojowe } \\
\text { i wykorzystanie wielu } \\
\text { metod dają silniejsze } \\
\text { efekty niż badania } \\
\text { danych archiwalnych, } \\
\text { - subiektywne mierniki } \\
\text { wyników firmy dają } \\
\text { silniejsze efekty niż } \\
\text { mierniki obiektywne, } \\
\text { - kombinowany pomiar } \\
\text { „oburęczności” wska- } \\
\text { zuje na silniejszą rela- } \\
\text { cję z wynikami firmy } \\
\text { niż pomiar oparty na } \\
\text { zrównoważeniu, } \\
\text { - wyniki działalności } \\
\text { są silniejsze na bardziej } \\
\text { zagregowanych pozio- } \\
\text { mach analizy, } \\
\text { - wpływ „oburęczno- } \\
\text { ści” na wyniki firmy } \\
\text { jest słabszy w przemy- } \\
\text { śle wytwórczym }\end{array}$ & $\begin{array}{l}\text { - zasoby identyfiko- } \\
\text { wane przez badaczy } \\
\text { jako strategiczne są } \\
\text { dodatnio związane } \\
\text { z efektywnością orga- } \\
\text { nizacyjną, } \\
\text { - miary zasobów, które } \\
\text { spełniają kryteria } \\
\text { teorii zasobowej mają } \\
\text { silniejszy pozytywny } \\
\text { związek z efektywno- } \\
\text { ścią organizacyjną niż } \\
\text { miary, które tych kry- } \\
\text { teriów nie spełniają, } \\
\text { - związek zasobów } \\
\text { z efektywnością jest } \\
\text { silniejszy, kiedy miary } \\
\text { efektywności są nieza- } \\
\text { leżne od potencjalnej } \\
\text { apropriacji wartości, } \\
\text { - wpływ strategicznych } \\
\text { zasobów na efektyw- } \\
\text { ność organizacyjną } \\
\text { jest ważny i relatywnie } \\
\text { stały w wielu różnych } \\
\text { kontekstach }\end{array}$ & $\begin{array}{l}\text { - pozytywna, aczkol- } \\
\text { wiek słaba korelacja } \\
\text { pomiędzy zmiennymi, } \\
\text { - określenie nowych } \\
\text { czterech mechani- } \\
\text { zmów, które wpływają } \\
\text { na rozwój zaufania } \\
\text { w czasie, } \\
\text { - poszczególne } \\
\text { mechanizmy mogą dać } \\
\text { zarówno pozytywny, } \\
\text { jak i negatywny efekt } \\
\text { lub mogą nie oddziały- } \\
\text { wać wcale, co ograni- } \\
\text { cza wzgląd badawczy } \\
\text { i implikuje potrzebę } \\
\text { dalszych badań empi- } \\
\text { rycznych }\end{array}$ \\
\hline
\end{tabular}

Źródło: opracowanie własne na podstawie [Junni et al. 2013, s. 299-312; Crook et al. 2008, s. 1141-1154; Vanneste, Puranam i Kretschmer 2014, s. 1891-1902].

\section{Podsumowanie}

Każde pojedyncze badanie empiryczne ma swoje ograniczenia, stąd połączenie wyników wielu różnych badań stwarza możliwość ich częściowej neutralizacji poprzez skorygowanie niektórych zakłóceń spowodowanych 
błędami pomiarowymi, błędami próby, projektowaniem badań czy kontekstem badawczym. Tę możliwość daje właśnie metoda metaanalizy, która jest zbiorczą analizą ilościową wyników różnych badań dotyczących tego samego problemu badawczego i której celem jest przedstawienie dla nich sumarycznego wniosku statystycznego [Sauerbrei i Blettner 2003]. Mimo wielu wspomnianych jej zalet, które niewątpliwie stanowią przesłankę do jej zastosowania w różnych naukach, w tym naukach o zarządzaniu, również i ta metoda ma swoje ograniczenia. Najczęściej wskazuje się, że zbytnio polega na statystyce z pominięciem intuicji, włącza do jednej analizy badania zbyt rozbieżne lub słabe metodologicznie, niewystarczająco precyzyjnie definiuje konstrukty, co utrudnia operacjonalizację wyniku obserwowanego w niezależnych od siebie badaniach, oraz koncentruje się na badaniach nad anglosaską populacją, nie uwzględniając często prac niepublikowanych [Matt i Navarro 1997, s. 1-32; Hunt 1997]. Ponadto metaanaliza jest przeznaczona przede wszystkim do badań ilościowych, określających wielkości efektu, pomijając prace konceptualne, komentatorskie, skoncentrowane na proponowaniu modeli matematycznych, obrazujące wyniki badań jakościowych, analizy danych wtórnych, wywiady czy studia przypadków [King i He 2005, s. 671], chociaż w odniesieniu do tych ostatnich można spotkać propozycje metodyki jakościowej metaanalizy służącej połączeniu wyników wielu badań przeprowadzonych metodą case study [Stall-Meadows i Hyle 2010, s. 412-418]. Dlatego też ciekawym kierunkiem dalszych badań może być rozwinięcie metodologiczne metody metaanalizy, która pozwoliłaby łączyć wyniki wielu badań ilościowych z wynikami wielu badań jakościowych.

Mimo że metaanaliza jest metodą analizy po fakcie (post hoc) i ma swoje ograniczenia, jej popularność, zwłaszcza w naukach o zarządzaniu, wzrasta, gdyż charakteryzuje ją przede wszystkim większy obiektywizm badawczy, a przez to bardziej rzetelne i trafne wnioski wyciągane na podstawie jej wyników.

\section{Literatura}

Aguinis H., Dalton D.R., Bosco F.A., Pierce C.A., Dalton C.M. [2011], Meta-analytic Choices and Judgment Calls: Implications for Theory Building and Testing, Obtained Effect Sizes, and Scholarly Impact, ,Journal of Management”, vol. 37, nr 1, https://doi. org $/ 10.1177 / 0149206310377113$.

Barney J.B. [1991], Firm Resources and Sustained Competitive Advantage, „Journal of Management”, vol. 17, nr 1, https://doi.org/10.1177/014920639101700108.

Barylski M., Górska-Ciebiada M., Ciebiada M. [2011], Geriatria oparta na faktach pytania i odpowiedzi. Podstawowe pojęcia - część II, „Geriatria”, nr 5.

Campbell-Hunt C. [2000], What Have We Learned about Generic Competitive Strategy? A Meta-analysis, „Strategic Management Journal”, vol. 21, nr 2, https://doi. org/10.1002/(sici)1097-0266(200002)21:2<127::aid-smj75>3.3.co;2-t. 
Cankurtaran P., Langerak F., Griffin A. [2013], Consequences of New Product Development Speed: A Meta-analysis, ,Journal of Product Innovation Management”, vol. 30, nr 3, https://doi.org/10.1111/jpim.12011.

Cooper H. [2010], Research Synthesis and Meta-analysis: A Step-by-step Approach, Sage Publications, Thousand Oaks.

Crook T.R., Ketchen D.J., Combs J.G., Todd S.Y. [2008], Strategic Resources and Performance: A Meta-analysis, „Strategic Management Journal”, vol. 29, nr 11, https://doi. org/10.1002/smj.703.

Damanpour F. [1991], Organizational Innovation: A Meta-analysis of Effects of Determinants and Moderators, „Academy of Management Journal”, vol. 34, nr 3, https://doi. org/10.2307/256406.

Eysenck H.J. [1978], An Exercise in Mega-silliness, „American Psychologist”, vol. 33, nr 5.

Field A.P. [2001]. Meta-analysis of Correlation Coefficients: A Monte Carlo Comparison of Fixed-and Random-effects Methods, „Psychological Methods”, vol. 6, nr 2, https:// doi.org/10.1037//1082-989x.6.2.161.

Glass G.V. [1976], Primary, Secondary and Meta-analysis of Research, „Educational Researcher", vol. 5, nr 10, https://doi.org/10.2307/1174772.

Gondek A., Mazur K. [2014], Metodyka metaanalizy w naukach o zarzadzaniu [w:] Podstawy metodologii badań w naukach o zarzadzaniu, red. W. Czakon, Oficyna a Wolters Kluwer business, Warszawa.

The Handbook of Research Synthesis [1994], eds H. Cooper, L.V. Hedges, Russel Sage Foundation, New York.

Hedges L.V., Olkin I. [1985], Statistical Methods for Meta-analysis, Academic Press, London.

Heugens P.P., Lander M.W. [2009], Structure! Agency! (and Other Quarrels): A Meta- analysis of Institutional Theories of Organization, „Academy of Management Journal", vol. 52, nr 1, https://doi.org/10.5465/amj.2009.36461835.

Hunt M. [1997], How Science Takes Stock, Russell Sage Foundation, New York.

Hunter J.E. [2001], The Desperate Need for Replications, „Journal of Consumer Research", vol. 28, no 1.

Hunter J.E., Schmidt F.L. [1990, 2004], Methods of Meta-analysis: Correcting Error and Bias in Research Findings, Sage Publications, Thousand Oaks.

Hunter J.E., Schmidt F.L. [2015], Methods of Meta-analysis: Correcting Error and Bias in Research Findings, 3rd ed., Sage Publications, London.

Junni P., Sarala R.M., Taras V., Tarba S.Y. [2013], Organizational Ambidexterity and Performance: A Meta-analysis, „The Academy of Management Perspectives”, vol. 27, nr 4, https://doi.org/10.5465/amp.2012.0015.

King D.R., Dalton D.R., Daily C.M., Covin J.G. [2004], Meta-analyses of Post-acquisition Performance: Indications of Unidentified Moderators, „Strategic Management Journal", vol. 25, nr 2, https://doi.org/10.1002/smj.371.

King W.R., He J. [2005], Understanding the Role and Methods of Meta-analysis in IS Research, „Communications of the Association for Information Systems”, vol. 16, nr 1.

King B., Minium E. [2009], Statystyka dla psychologów i pedagogów, Wydawnictwo Naukowe PWN, Warszawa.

Kleka P. [2011], Statystyczne kryteria przydatności raportu z badań do metaanalizy [w:] Metodologia badań społecznych. Wybór tekstów, red. J. Brzeziński, Zysk i S-ka, Poznań. 
Lipsey M.W., Wilson D.B. [2001], Practical Meta-analysis, Sage Publications no 49, Thousand Oaks.

Matera J., Czapska J. [2014], Zarys metody przegladu systematycznego w naukach społecznych, IBE, Warszawa.

Matt G.E., Navarro A.M. [1997], What Meta-analyses Have and Have Not Taught Us about Psychotherapy Effect: A Review and Future Directions, „Clinical Psychology Review", vol. 17, nr 1, https://doi.org/10.1016/s0272-7358(96)00042-6.

Meyer J.P., Stanley D.J., Herscovitch L., Topolnytsky L. [2002], Affective, Continuance, and Normative Commitment to the Organization: A Meta-analysis of Antecedents, Correlates, and Consequences, ,Journal of Vocational Behavior”, vol. 61, nr 1, https:// doi.org/10.1006/jvbe.2001.1842.

Pearson K. [1904], Report on Certain Enteric Fever Inoculation Statistics, „British Medical Journal", $\mathrm{nr}$ 2, https://doi.org/10.1136/bmj.2.2288.1243.

Rosenthal R. [1978], Combining Results of Independent Studies, „Psychological Bulletin", vol. 85, nr 1, https://doi.org/10.1037//0033-2909.85.1.185.

Rosenthal R. [1995], Writing Meta-analytic Reviews, „Psychological Bulletin”, vol. 118, nr 2, https://doi.org/10.1037//0033-2909.118.2.183.

Rosenthal R., Rubin D.B. [1982], Comparing Effects Sizes of Independent Studies, „Psychological Bulletin", vol. 92, nr 2, https://doi.org/10.1037//0033-2909.92.2.500.

Rosenthal R., Rubin D.B. [2003] r Equivalent: A Simple Effect Size Indicator, „Psychological Methods", vol. 8, nr 4, https://doi.org/10.1037/1082-989x.8.4.492.

Sack H.S., Berrier J., Reitman D., Ancona-Berk V.A. [1987], Meta-analyses of Randomized Controlled Trials, „New England Journal of Medicine”, vol. 316, nr 8.

Sagan A. [2009], Metaanaliza danych w marketingu zorientowanym na dowody-orientacja kliniczna $w$ badaniach rynkowych i marketingowych, „Prace Naukowe Uniwersytetu Ekonomicznego we Wrocławiu", nr 51.

Sauerbrei W., Blettner M. [2003], Issues of Traditional Reviews and Meta-analyses of Observational Studies in Medical Research [w:] Meta-analysis: New Developments and Applications in Medical and Social Sciences, ed. R. Schulze, H. Holling, D. Böhning, Hogrefe \& Huber, München.

Sibińska A., Krawiec V. [2014], Wykorzystanie meta-analizy do badań nad zachowaniami konsumentów, „Handel Wewnętrzny”, nr 1.

Simon W. [2010a], Meta-analiza w badaniach nad skutecznościa psychoterapii. Czesść I: Pytania badawcze, przeglad literatury, kodowanie danych, „Psychiatria i Psychoterapia", t. 6, nr 2.

Simon W. [2010b], Meta-analiza w badaniach nad skutecznościa psychoterapii. Część II: Rodzaje wielkości efektu, binominalna wielkość efektu, testowanie homogeniczności, zmienne mediujace i moderujace, „Psychiatria i Psychoterapia”, t. 6, nr 2.

Simon W. [2010c], Meta-analiza w badaniach nad skutecznościa psychoterapii. Część III: Losowy i stały model efektu, ważenie wielkości efektu, przycinanie danych, aplikacje, przykłady meta-analiz, „Psychiatria i Psychoterapia”, t. 6, nr 2.

Smith L.M., Glass G.V. [1977], Meta-analysis of Psychotherapy Outcome Studies, „American Psychologist”, vol. 32, nr 9, https://doi.org/10.1037//0003-066x.32.9.752.

Stall-Meadows C., Hyle A. [2010], Procedural Methodology for a Grounded Meta-analysis of Qualitative Case Studies, „International Journal of Consumer Studies”, vol. 34, nr 4, https://doi.org/10.1111/j.1470-6431.2010.00882.x. 
Vanneste B.S., Puranam P., Kretschmer T. [2014], Trust over Time in Exchange Relationships: Meta-analysis and Theory, „Strategic Management Journal”, vol. 35, nr 12, https://doi.org/10.1002/smj.2198.

Zakrzewska M. [2004], Konfirmacyjna analiza czynnikowa w ujęciu pakietu statystycznego LISREL 8.51 Karla G. Joreskoga i Daga Sorboma [w:] Metodologia badań psychologicznych. Wybór tekstów, red. J. Brzeziński, Wydawnictwo Naukowe PWN, Warszawa.

Zakrzewska-Bielawska A. [2016], Ambidexterity - światowe trendy eksploracji w naukach o zarządzaniu, „Przegląd Organizacji”, nr 1.

\section{The Use of Meta-analysis in Management Science (Abstract)}

The paper discusses meta-analysis and its uses in management science. The first part presents the essence of the method, its main characteristics and its various stages as a procedure, with particular emphasis on the effects of different measures it uses. The next part of the paper introduces selected examples of the use of meta-analysis to examine problems in management science. Three of them are discussed in detail, each with a different aim for adopting this method. The summary indicates the main limitation of the use of meta-analysis as a research method and describes the direction of its methodological development.

Keywords: meta-analysis, methodology, management sciences, examples of use. 